\title{
Effects of growth hormone treatment on the leptin system and on energy expenditure in abdominally obese men
}

\author{
Cecilia Karlsson, Kaj Stenlöf ${ }^{1}$, Gudmundur Johannsson, Per Mårin ${ }^{1}$, Per Björntorp ${ }^{1}$, Bengt-Åke Bengtsson,
} Björn Carlsson, Lena M S Carlsson and Lars Sjöström ${ }^{1}$

Research Centre for Endocrinology and Metabolism, Department of Medicine, and ${ }^{1}$ Department of Medicine, Sahlgrenska University Hospital, Göteborg, Sweden

(Correspondence should be addressed to K Stenlöf, Department of Medicine, Sahlgrenska University Hospital, S-413 45 Göteborg, Sweden)

\begin{abstract}
The present study has examined the short- and long-term effects of growth hormone (GH) treatment on the leptin system and energy expenditure. Thirty male individuals with abdominal obesity were randomised to GH or placebo treatment in a 9-month, double-blind study. The dose of GH was $9.5 \mu \mathrm{g} / \mathrm{kg}$, administered subcutaneously every evening. Serum leptin concentrations were measured by a human leptin RIA. Total RNA was isolated from adipose tissue biopsies and leptin mRNA levels were determined by a semi-quantitative reverse transcriptase-PCR assay. Body composition was determined by potassium-40 and the basal metabolic rate (BMR) was measured by a computerised, ventilated, open-hood system.

As compared with placebo, an overall decrease in serum leptin concentrations as assessed by the area under the curve $($ AUC) $(P<0.05)$ and an increase in BMR (AUC, $P<0.05)$ were observed during GH treatment. The overall GH-induced changes were due to marked changes in serum leptin concentrations and BMR after 6 weeks of treatment. After 9 months of GH treatment there was a significant reduction in body fat (BF) while serum leptin concentrations and BMR did not differ from baseline values. Leptin mRNA levels did not change over the study period.

We speculate that long-term GH treatment induces a new energy balance steady state with decreased $\mathrm{BF}$ stores. The effects of $\mathrm{GH}$ on the leptin system is suggested to be of importance for the maintenance of a lower BF mass.
\end{abstract}

European Journal of Endocrinology 138 408-414

\section{Introduction}

Leptin, the protein product of the ob gene (1), is produced by adipocytes and thought to play a critical role in the regulation of body fat (BF) stores. Serum leptin concentrations are positively correlated to the amount of $\mathrm{BF}(2,3)$ and it has been suggested that leptin acts in an endocrine fashion by reporting the size of adipose tissue mass to hypothalamic centres $(4,5)$. Furthermore, weight loss, as an effect of dieting, has been found to decrease serum leptin concentrations $(6,7)$ and resting energy expenditure (6) in obese women. Sustained weight loss leads to a decrease in plasma leptin concentrations adjusted for $\mathrm{BF}$ in obese women but not in women of normal weight (6). It has been suggested that the decrease in leptin concentrations after weight loss could contribute to the strong tendency for weight regain after successful dieting (6).

Obesity is associated with disturbances in the growth hormone (GH)/insulin-like growth factor-I (IGF-I) axis and spontaneous GH secretion is decreased in obese subjects (8). GH treatment increases energy expenditure (EE) in man $(9,10)$ and promotes BF loss in both man and rodents $(11,12)$. Recent reports also indicate an interaction between the $\mathrm{GH}$ system and the leptin system (13-15). However, the results of studies on the effect of GH on serum leptin levels are conflicting and both a decrease (13) and an increase (14) in serum leptin concentrations have been reported during $\mathrm{GH}$ treatment in man.

The aims of the present study were to examine the effects of short- and long-term GH treatment on the leptin system and on EE in men with abdominal obesity.

\section{Subjects and methods}

\section{Study subjects}

The subjects of this study were 30 males with abdominal obesity (48 to 66 years of age). The effects of 9 months of treatment with GH on body composition, blood pressure, lipid and glucose metabolism have previously been reported for these subjects (11). The 9 months of treatment with $\mathrm{GH}$ decreased total $\mathrm{BF}$ by $9.2 \pm 2.4 \% \quad(P=0.03) \quad$ compared with placebo 
treatment. In the present study the effects of $\mathrm{GH}$ treatment on the leptin system and EE are reported.

The subjects were recruited by advertisements in a local newspaper. The criteria for inclusion were age approximately between 50 and 65 years, body mass index (BMI) between 25 and $35 \mathrm{~kg} / \mathrm{m}^{2}$, serum IGF-I concentration below $160 \mu \mathrm{g} / \mathrm{l}$ (low to normal) and a waist:hip ratio of more than 0.95. The criteria for exclusion were overt diabetes mellitus, previous cardiovascular event or heart disease.

In the GH-treated group, two patients were receiving treatment for hypertension with both atenolol (100 mg/ day) and nifedipine ( $40 \mathrm{mg} /$ day) and one patient was treated with salmeterol and terbutaline inhalations due to mild asthma. In the placebo-treated group, one patient was receiving paroxetin $(10 \mathrm{mg} /$ day $)$ due to a depressive tendency. All medication was kept stable during the study period.

\section{Study design}

This study was designed as a 9-month, randomised, double-blind and placebo-controlled study of the administration of $\mathrm{GH}$. The patients were studied as outpatients. Informed consent was obtained from each patient before the study. The study was approved by the Ethics Committee at the University of Göteborg and by the Swedish Medical Products Agency, Uppsala, Sweden.

\section{Treatment}

The dose of $\mathrm{GH}$ was $9.5 \mu \mathrm{g} / \mathrm{kg}$ administered as a subcutaneous injection before bedtime $(0.20 \mathrm{IU} / \mathrm{kg}$ body weight/week). Due to peripheral oedema and arthralgia the dose was reduced by half in four subjects. For more details on side-effects, see reference 11 . One subject in the GH-treated group was taken off treatment at 8 months after he had experienced an intracerebral haemorrhage. The placebo vials contained the same vehicle as the $\mathrm{GH}$ vials and the two preparations were visually indistinguishable. Compliance was assessed by counting the returned empty vials.

\section{Calorimetric methods}

Basal metabolic rate (BMR) was determined by indirect calorimetry in a computerised, ventilated, openhood system (Deltatrac, Datex Instrumentarium Corp., Helsinki, Finland). The examinations were performed according to standardised conditions in the morning after an overnight fast and after a 30 min rest on the bed used for the examinations. Respiratory data were then collected every minute for $30 \mathrm{~min}$. BMR was calculated as the mean EE over the $30 \mathrm{~min}$ and expressed as $\mathrm{kcal} \cdot 24 \mathrm{~h}^{-1}$.

The mathematical procedures followed those described by Ferrannini (16). The protein oxidation was calculated from urinary nitrogen excretion over $24 \mathrm{~h}$ and the carbohydrate and lipid oxidations were calculated from non-protein $\mathrm{RQ}$. The $\mathrm{O}_{2}$ and $\mathrm{CO}_{2}$ analysers were calibrated before and after each experiment by using $\mathrm{O}_{2} / \mathrm{CO}_{2}$ mixtures of known composition. The overall standard error of a single determination was $4 \%$ (9). The technical error of the system, checked at intervals by ethanol combustion experiments, was about 3\% (9). Reference values for BMR taking account of sex, age, height and weight were obtained from the equations suggested by Schofield (17). The dietary intake was analysed before the initiation of the study using a previously validated dietary questionnaire (18). The study subjects had a daily total energy intake of $2235 \pm 654 \mathrm{kcal}$ (mean \pm s.D.) (protein $84 \pm 21 \mathrm{~g}$, fat $92 \pm 36 \mathrm{~g}$, carbohydrate $231 \pm 68 \mathrm{~g}$ ) and they were instructed to maintain their usual diet over the study period.

\section{Body composition}

Body weight was measured with the patients dressed in underwear and was determined to the nearest $0.1 \mathrm{~kg}$ on a calibrated scale (Sartorius 300-F). Body height was measured to the nearest $0.01 \mathrm{~m}$ in the standing position. BMI was calculated as body weight divided by height ${ }^{2}$. Waist and hip circumferences were measured using a non-elastic tape with the subjects standing, according to standardised procedures.

Total body potassium was measured by counting the emission of $1.46 \mathrm{MeV}$ gamma radiation from the naturally occurring ${ }^{40} \mathrm{~K}$ isotope in a high-sensitive $3 \pi$ whole-body counter with a coefficient of variation (C.V.) of $2.2 \%$. Fat free mass (FFM) was estimated by assuming a potassium content of $64.7 \mathrm{mmol} / \mathrm{kg} \mathrm{FFM} \mathrm{and} \mathrm{BF} \mathrm{was}$ calculated as body weight minus FFM (19).

\section{RNA isolation and cDNA synthesis}

Adipose tissue, approximately $200 \mathrm{mg}$, was obtained by needle biopsies of abdominal subcutaneous fat. The biopsies were immediately frozen in liquid nitrogen and stored at $-80{ }^{\circ} \mathrm{C}$ until analysis. Total RNA was isolated from the adipose tissue biopsies essentially as described by Chomczynski \& Sacchi (20), with the following modifications: during the extraction chloroform was increased to a ratio of 1:2 chloroform:phenol and an additional ethanol precipitation was included. Firststrand cDNA was generated from $1 \mu \mathrm{g}$ denatured RNA $\left(2 \mathrm{~min}\right.$ at $\left.85^{\circ} \mathrm{C}\right)$ in $1 \times$ reverse transcriptase buffer ( $50 \mathrm{mmol} / \mathrm{l}$ Tris-HCl, $\mathrm{pH} 8.3,50 \mathrm{mmol} / \mathrm{l} \mathrm{KCl}$, $10 \mathrm{mmol} / \mathrm{l} \mathrm{MgCl}_{2}, 10 \mathrm{mmol} / \mathrm{l}$ dithiothreitol, $0.5 \mathrm{mmol} / \mathrm{l}$ spermidine), $20 \mathrm{U}$ AMV reverse transcriptase (Promega, Madison, WI, USA), $20 \mathrm{U}$ RNAsin (Promega), $0.5 \mu \mathrm{g}$ random hexamers (Boehringer Mannheim, Mannheim, Germany) and $5 \mathrm{mmol} / \mathrm{l}$ deoxynucleotides (dNTP) (Boehringer Mannheim) in a final volume of $25 \mu \mathrm{l}$ ( $5 \mathrm{~min}$ at $22^{\circ} \mathrm{C}, 50 \mathrm{~min}$ at $42{ }^{\circ} \mathrm{C}$ and $4 \mathrm{~min}$ at $72{ }^{\circ} \mathrm{C}$ ). 


\section{Analysis of leptin mRNA levels}

The method for determining leptin mRNA levels by a semi-quantitative reverse transcriptase-polymerase chain reaction (RT-PCR) assay has previously been described (21). In short, aliquots from the same cDNA preparation were used as templates in two separate PCRs using biotinylated primers ( $10 \mathrm{pmol}$ each) specific for leptin cDNA or $\beta$-actin cDNA respectively. PCR was carried out in $1 \times$ PCR buffer with $0.2 \mathrm{mmol} / \mathrm{l} \mathrm{dNTP,} 2.5 \mathrm{U}$ Taq polymerase (Boehringer Mannheim) and $2.5 \mu \mathrm{Ci}$ $\left[{ }^{33} \mathrm{P}\right]$ dATP (Amersham International, Little Chalfont, Bucks, UK) in a final volume of $50 \mu \mathrm{l}$ using a GeneAmp PCR system 9600 (Perkin Elmer Cetus, Norwalk, CT, USA). Negative controls were included to verify the lack of contamination. Aliquots from each PCR were dispensed into streptavidin-coated microtitre plates (Streptavidin Covalent Strips, Wallac Oy, Turku, Finland) and counted in a micro-liquid scintillation counter (Wallac Oy). Leptin mRNA levels were estimated by calculating the ratio between the radioactivity in samples amplified with primers specific for leptin and $\beta$-actin cDNA respectively.

\section{Biochemical analysis}

Blood samples were drawn in the morning after an overnight fast.

Serum leptin concentrations were determined in duplicate by a human leptin RIA (Linco Research, Inc., St Charles, MO, USA). The limit of sensitivity for the assay was $0.5 \mu \mathrm{g} / \mathrm{l}$. The intra-assay C.V. was $6.3 \%$ at a leptin concentration of $15.6 \mu \mathrm{g} / \mathrm{l}$. The interassay coefficients of variation were $8.8 \%$ and $5.2 \%$ at serum leptin concentrations of $2.9 \mu \mathrm{g} / \mathrm{l}$ and $15.0 \mu \mathrm{g} / \mathrm{l}$ respectively.

Serum IGF-I concentrations were determined by a hydrochloric acid-ethanol extraction RIA (Nichols Institute Diagnostics, San Juan Capistrano, CA, USA).

Serum free thyroxine (free $\mathrm{T}_{4}$ ) and free 3,5,3'-triiodothyronine (free $\mathrm{T}_{3}$ ) concentrations were analysed using ligand analogue RIAs (Amerlex-M, Amersham International).

Urinary nitrogen excretion was determined by chemiluminescence (Anteck Instruments, Houston, TX, USA).

\section{Statistical methods}

All the analyses were performed according to the principle of intention-to-treat. Descriptive statistical results are presented in the tables as the means and standard errors of the mean (s.E.M.). A two-stage method was used to test the overall effect of treatment. First, repeated measurements from each patient were reduced to one summary variable, reflecting the individual response to treatment. In the present study, the area under the curve (AUC) was used as the summary variable (i.e. increase or decrease from baseline levels). Secondly, the effect of treatment (AUC) was analysed using Student's $t$-test between treatment groups and, when appropriate, with the elimination of the influence of the pre-treatment level using Mantels test. Delta values were compared using Student's $t$-test between groups. Pearson's correlation coefficients were calculated between variables of interest. Multivariate analyses were performed using multiple regression analysis. Multiple $R^{2}$ values were adjusted for degrees of freedom and expressed as a percentage. A $P$ value of less than 0.05 was considered significant.

\section{Results}

\section{Leptin}

As compared with placebo, $\mathrm{GH}$ treatment resulted in an overall reduction of serum leptin concentrations (AUC, $P<0.05$ ) (Fig. 1A) but no change in leptin mRNA levels (leptin mRNA/actin mRNA) (Table 1). The change in serum leptin concentrations adjusted for BF (leptin/BF) failed to reach statistical significance (AUC, $P<0.10$ )

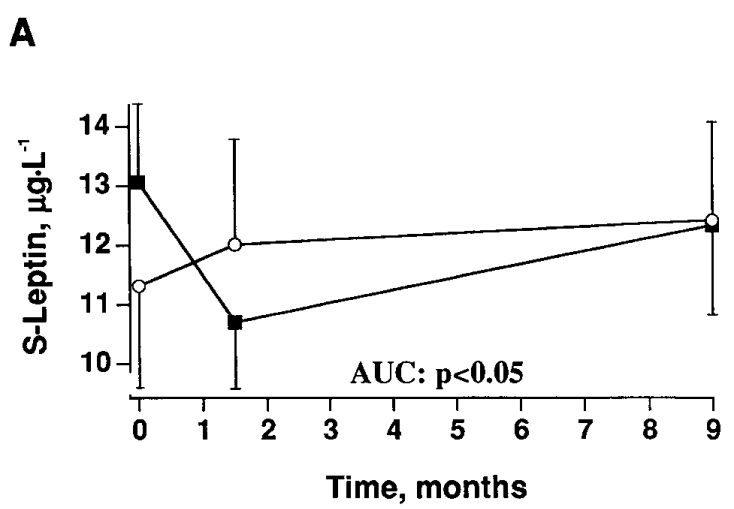

B

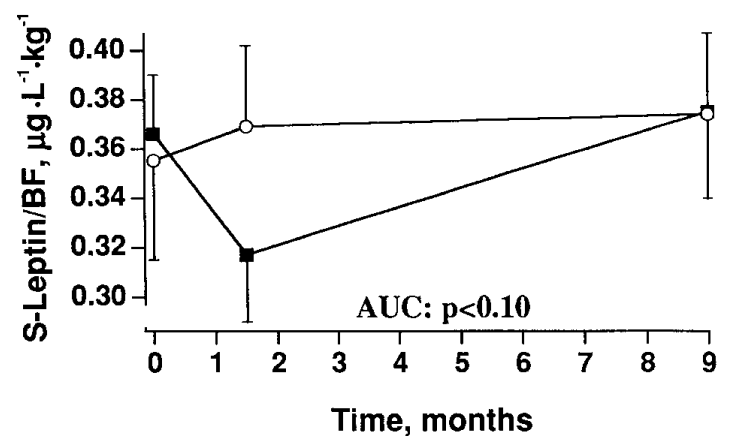

Figure 1 The effects of 9 months of treatment with GH on serum (S) leptin concentrations $(\mathbf{A})$ and serum leptin/BF ratio $(\mathbf{B})$ in abdominally obese male subjects. (GH treatment, $\mathbf{\square}$; placebo, $\mathrm{O}$ ). The $P$ value denotes differences in terms of AUC in the two treatment groups over 9 months. 
Table 1 Leptin mRNA/actin mRNA, serum IGF-I concentrations and the free $T_{3} /$ free $T_{4}$ ratio at baseline and during 9 months of GH or placebo treatment in 30 abdominally obese male subjects. Values are means \pm S.E.M.

\begin{tabular}{|c|c|c|c|c|c|}
\hline Variable & Baseline & 6 weeks & 6 months & 9 months & $P$ value AUC \\
\hline \multicolumn{6}{|l|}{ Leptin mRNA } \\
\hline $\mathrm{GH}(n=7)$ & $0.22 \pm 0.05$ & $0.21 \pm 0.03$ & nd & $0.27 \pm 0.05$ & \multirow[t]{2}{*}{ ns } \\
\hline Placebo $(n=8)$ & $0.22 \pm 0.04$ & $0.18 \pm 0.03$ & nd & $0.34 \pm 0.12$ & \\
\hline \multicolumn{6}{|l|}{ IGF-I $(\mu \mathrm{g} / \mathrm{I})$} \\
\hline $\mathrm{GH}$ & $134 \pm 8.3$ & $338 \pm 16$ & $320 \pm 23$ & $268 \pm 23$ & \multirow{2}{*}{$<0.001$} \\
\hline Placebo & $120 \pm 11$ & $121 \pm 12$ & $130 \pm 12$ & $119 \pm 12$ & \\
\hline \multicolumn{6}{|l|}{ Free $T_{3} /$ free $T_{4}$} \\
\hline $\mathrm{GH}$ & $0.40 \pm 0.01$ & $0.50 \pm 0.02$ & $0.47 \pm 0.02$ & $0.41 \pm 0.02$ & \multirow[t]{2}{*}{$<0.01$} \\
\hline Placebo & $0.42 \pm 0.02$ & $0.43 \pm 0.02$ & $0.43 \pm 0.03$ & $0.44 \pm 0.03$ & \\
\hline
\end{tabular}

nd, not defined; ns, not significant.

(Fig. 1B) in the GH-treated group compared with the controls.

The overall GH-induced change $(\Delta)$ in serum leptin concentrations was due to a marked reduction at 6 weeks $(\Delta 0-6$ weeks, $\mathrm{GH}:-2.36 \pm 0.59$ vs placebo: $\left.0.70 \pm 0.79 \mu \mathrm{g} \cdot \mathrm{l}^{-1} ; \quad P<0.01\right)$. After 9 months, no difference in the effect on serum leptin concentrations $(\Delta$ 0-9 months, GH: $-0.73 \pm 0.96$ vs placebo: $1.09 \pm 0.73 \mu \mathrm{g} \cdot \mathrm{l}^{-1}$; NS) (Fig. 1A) or leptin/BF ( $\Delta 0-9$ months, GH: $0.02 \pm 0.03$ vs placebo: $0.02 \pm$ $0.02 \mu \mathrm{g} \cdot \mathrm{l}^{-1} \cdot \mathrm{kg}^{-1}$; not significant (NS)) (Fig. 1B) could be demonstrated between the two treatment groups.

\section{Energy expenditure}

Analysed over the total period of 9 months, BMR was increased by GH as compared with placebo (AUC, $P<0.05$ ) (Table 2). The overall effect was explained by a $\mathrm{GH}$-induced increase in BMR between 0 and 6 weeks $(\Delta$ 0-6 weeks, GH: $159 \pm 34$ vs placebo: $-0.3 \pm$
$34 \mathrm{kcal} \cdot 24 \mathrm{~h}^{-1} ; P<0.01$ ) (Table 2). A similar increase after 6 weeks was found in BMR adjusted for FFM $(\Delta$ 0-6 weeks, $\mathrm{GH}: 1.3 \pm 0.4$ vs placebo: $-0.3 \pm$ $\left.0.5 \mathrm{kcal} \cdot 24 \mathrm{~h}^{-1} \cdot \mathrm{kg}^{-1} ; \mathrm{P}<0.05\right)$. After 9 months, BMR ( $\Delta$ 0-9 months, GH: $31 \pm 53$ vs placebo: $-12 \pm$ $42 \mathrm{kcal} \cdot 24 \mathrm{~h}^{-1}$; NS) and BMR adjusted for FFM $(\Delta 0-$ 9 months, GH: $-0.4 \pm 0.7$ vs placebo: $-0.4 \pm 0.6$ $\mathrm{kcal} \cdot 24 \mathrm{~h}^{-1} \cdot \mathrm{kg}^{-1}$; NS) were similar in the two treatment groups.

Lipid oxidation was increased by GH (AUC $P<0.01)$ and this was mainly due to a transient GH-induced increase at 6 weeks $(\Delta 0-6$ weeks, GH: $20.5 \pm 9.5$ vs placebo: $-16.6 \pm 5.2 \mathrm{mg} \cdot \mathrm{min}^{-1} ; P<0.01$ ) (Table 2).

\section{IGF-I and thyroid hormones}

Serum IGF-I concentrations and the free $\mathrm{T}_{3} /$ free $\mathrm{T}_{4}$ ratio increased during $\mathrm{GH}$ treatment compared with placebo (IGF-I AUC, $P<0.001$; free $\mathrm{T}_{3} /$ free $\mathrm{T}_{4}$ AUC, $P<0.01$ ) (Table 1). After 9 months, the mean serum IGF-I

Table 2 Body weight, body fat (BF), fat free mass (FFM) and energy expenditure at baseline and during 9 months of GH or placebo treatment in 30 abdominally obese male subjects. Values are means \pm S.E.M.

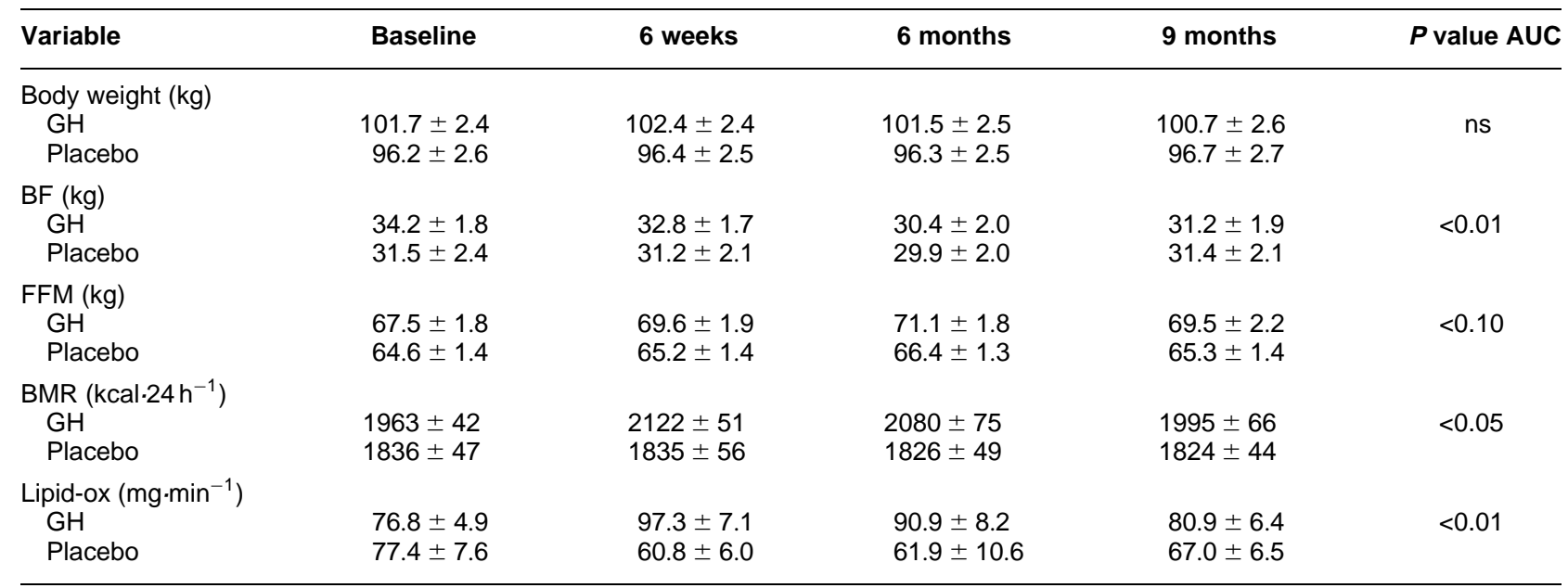

Lipid-ox, lipid oxidation; ns, not significant. 
concentrations had approximately doubled in the GHtreated group (Table 1). The overall increase in the free $\mathrm{T}_{3} /$ free $\mathrm{T}_{4}$ ratio was due to an increase at 6 weeks $(\Delta 0-$ 6 weeks, GH: $0.09 \pm 0.02$ vs placebo: $0.00 \pm 0.01$; $P<0.001$ ), but no effect could be demonstrated after 9 months $(\Delta 0-9$ months, GH: $0.01 \pm 0.02$ vs placebo: $0.02 \pm 0.01 ; \mathrm{NS})$.

\section{Correlations within the GH-treated group}

The increase in BMR between baseline and 6 weeks was positively correlated to the increase in serum IGF-I concentrations, the free $\mathrm{T}_{3} /$ free $\mathrm{T}_{4}$ ratio and FFM but not to changes in serum leptin concentrations (Table 3). No correlation was found between changes in serum leptin concentrations between baseline and 6 weeks and changes in body composition, serum IGF-I or thyroid hormone concentrations (not shown) during the same time period.

The decrease in BMR between 6 weeks and 9 months was positively correlated to changes in serum leptin concentrations and tended to be positively correlated to the decrease in the free $\mathrm{T}_{3} /$ free $\mathrm{T}_{4}$ ratio (Table 3 ).

In multiple regression analysis between baseline and 6 weeks of treatment, the change in FFM was no longer a predictor of the increase in BMR, while the increase in serum IGF-I concentrations $(P=0.042)$ and the free $\mathrm{T}_{3} /$ free $\mathrm{T}_{4}$ ratio $(P=0.040)$ remained significantly correlated to the increase in BMR (not shown). Multiple regression analysis of the decrease in BMR between 6 weeks and 9 months of treatment revealed that the decrease was positively related to the decrease in the free $\mathrm{T}_{3} /$ free $\mathrm{T}_{4}$ ratio and also positively related to changes in serum leptin concentrations when adjusted for changes in body composition (Table 4). A large reduction in BMR was therefore associated with a large reduction in free $\mathrm{T}_{3} /$ free $\mathrm{T}_{4}$ and a small increase in serum leptin concentrations. Conversely, a large increase in serum leptin concentrations was associated with a smaller reduction in BMR.

Table 3 Pearson's correlation coefficients between changes in BMR $(\triangle \mathrm{BMR})$ and changes $(\triangle)$ in body composition (body fat (BF) and fat free mass (FFM)), serum IGF-I concentrations, the free $T_{3} /$ free $T_{4}$ ratio $\left(\mathrm{FT}_{3} / \mathrm{FT}_{4}\right)$ and serum leptin concentrations between baseline and 6 weeks (0-6 weeks) and between 6 weeks and 9 months in the $\mathrm{GH}$-treated group.

\begin{tabular}{lcc}
\hline & \multicolumn{2}{c}{$\Delta$ BMR } \\
\cline { 2 - 3 } & $0-6$ weeks & 6 weeks-9 months \\
\hline$\Delta \mathrm{FFM}$ & $0.58^{*}$ & 0.36 \\
$\Delta \mathrm{BF}$ & -0.40 & 0.08 \\
$\Delta \mathrm{IGF}-\mathrm{I}$ & $0.73^{\star \star \star}$ & -0.07 \\
$\Delta \mathrm{FT}_{3} / \mathrm{FT}_{4}$ & $0.55^{*}$ & $0.48 \dagger$ \\
$\Delta$ Leptin $^{*}$ & 0.04 & $0.53^{*}$
\end{tabular}

$\dagger P<0.10,{ }^{*} P<0.05,{ }^{* * *} P<0.001$.
Table 4 Multiple regression analysis of changes in BMR $(\triangle \mathrm{BMR})$ between 6 weeks and 9 months by changes $(\Delta)$ in serum leptin concentrations, the free $\mathrm{T}_{3}$ /free $\mathrm{T}_{4}\left(\mathrm{FT}_{3} / \mathrm{FT}_{4}\right)$ ratio and body composition (body fat $(\mathrm{BF})$ and fat free mass (FFM))

\begin{tabular}{|c|c|c|}
\hline & \multicolumn{2}{|c|}{$\Delta B M R$} \\
\hline & T ratio & $P$ value \\
\hline $\begin{array}{l}\Delta \text { Leptin } \\
\Delta \mathrm{FT}_{3} / \mathrm{FT}_{4} \\
\Delta \mathrm{BF} \\
\Delta \mathrm{FFM} \\
R^{2} \text { adj } \\
P \text { value }\end{array}$ & $\begin{array}{r}2.87 \\
3.08 \\
-1.30 \\
-1.76\end{array}$ & $\begin{array}{l}0.017 \\
0.012 \\
0.225 \\
0.110\end{array}$ \\
\hline
\end{tabular}

$R^{2}$ adj, $R^{2}$ adjusted.

\section{Discussion}

The present study has examined the effects of 9 months of $\mathrm{GH}$ treatment on body composition in relation to serum leptin concentrations and EE in male subjects with abdominal obesity and low serum IGF-I concentrations. During the first 6 weeks of treatment, marked increases were observed in EE, lipid oxidation and the free $\mathrm{T}_{3} /$ free $\mathrm{T}_{4}$ ratio combined with a high rate of $\mathrm{BF}$ loss. During this initial period serum leptin concentrations decreased. At the end of the 9 months study period BF mass had settled at a significantly lower level, while $\mathrm{BMR}$, the free $\mathrm{T}_{3} /$ free $\mathrm{T}_{4}$ ratio and serum leptin concentrations were restored to pre-treatment levels. These findings indicate that GH treatment induces a sustained decrease in BF stores by inducing a new energy balance steady state, possibly mediated by effects on EE and serum concentrations of leptin and thyroid hormones.

$\mathrm{GH}$ increases $\mathrm{EE}$ in man $(9,10)$ and it has been suggested that this is a direct effect of $\mathrm{GH}$, but changes in other factors, such as thyroid hormones, may be of importance (10). In the present study, BMR and BMR adjusted for FFM increased after 6 weeks of $\mathrm{GH}$ treatment. The increase in BMR at 6 weeks was correlated to the increase in serum IGF-I concentrations and to the increase in free $\mathrm{T}_{3} /$ free $\mathrm{T}_{4}$ ratio. Leptin increases EE in rodents $(4,22,23)$, but this has not yet been demonstrated in man. The interaction between leptin and $\mathrm{GH}$ is complex. In addition to the effect of $\mathrm{GH}$ on $\mathrm{BF}$ mass, it is well known that nutritional status influences $\mathrm{GH}$ secretion. In humans, starvation leads to increased GH secretion (24) and obesity is associated with reduced GH secretion (8). In contrast, starvation leads to decreased $\mathrm{GH}$ secretion in rodents and leptin appears to be an important mediator of this effect, as administration of recombinant leptin to rodents during starvation normalises $\mathrm{GH}$ pulsatility (15).

During the first 6 weeks of GH treatment, serum leptin concentrations decreased and this is in agreement 
with a recent study of adults with GH deficiency treated with GH for 3 months (13). In contrast, when GH was given in combination with dexamethasone for 7 days, leptin levels increased (14). The differences in the effects of GH on serum leptin concentrations may be due to differences between the study groups, the treatment periods or the co-administration of dexamethasone. Under steady state conditions leptin levels are positively correlated to BF mass and appear to reflect adipocyte triglyceride stores. However, during rapid changes in nutritional status, such as starvation, the correlation is impaired and other factors including glucocorticoids, cytokines, insulin, beta adrenergic agonists and cAMP have been suggested as regulators of leptin expression (25). In our study, the decrease in serum leptin concentrations was not correlated to changes in body composition, EE, serum IGF-I or thyroid hormone concentrations, nor was it associated with changes in leptin mRNA levels. Previous studies have shown a strong correlation between leptin mRNA and serum leptin levels $(26,27)$. One possible explanation for the lack of correlation between leptin mRNA and serum leptin concentrations in this study is that leptin mRNA levels were determined in subcutaneous adipose tissue, while the effect of $\mathrm{GH}$ on $\mathrm{BF}$ is most pronounced in visceral fat depots (11). This is in line with a recent study demonstrating the site-specific regulation of leptin mRNA in adipose tissue by insulin infusion to rats. In that study, leptin mRNA was upregulated by insulin infusion in abdominal adipose tissue depots but not in subcutaneous ones (28). Other potential mechanisms for the discrepancy between serum leptin concentrations and leptin mRNA levels in subcutaneous adipose tissue, such as the effects of GH on distribution volume of leptin, leptin clearance (29), or binding proteins (30), have not yet been investigated.

After 9 months of GH treatment BF had decreased by $9.2 \pm 2.4 \%$ (11). During the same period serum leptin concentrations returned to pre-treatment levels. In addition, the stimulatory effect of $\mathrm{GH}$ on BMR and thyroid hormone deiodination declined and BMR and the free $\mathrm{T}_{3} /$ free $\mathrm{T}_{4}$ ratio were not different from pretreatment levels. In studies in which a decrease in $\mathrm{BF}$ has been obtained by low-calorie diets, plasma leptin concentrations (6), $\mathrm{T}_{4}$ to $\mathrm{T}_{3}$ deiodination (31) and $\mathrm{EE}$ (6) decrease. It has been suggested that these changes constitute mechanisms by which the body counteracts further BF loss. It has also been speculated that these changes could contribute to the strong tendency to gain weight after successful dieting (6). In the present study, the effect of $\mathrm{GH}$ on $\mathrm{BF}$ mass was most pronounced during the first months of treatment, indicating that short-term treatment is sufficient if the only aim is a reduced $\mathrm{BF}$ mass. However, long-term treatment with $\mathrm{GH}$ resulted in a decrease in BF mass without long-term alterations in serum leptin concentrations, thyroid hormone deiodination or BMR. It is therefore possible that long-term treatment with $\mathrm{GH}$ would be beneficial since the reversal of the initial decrease in serum concentrations of leptin may be of importance for the ability to maintain the lower BF mass achieved during GH treatment. In addition, our finding that a large increase in serum leptin concentrations between 6 weeks and 9 months of $\mathrm{GH}$ treatment was associated with a smaller reduction in BMR enhance the ability to maintain the lower BF mass.

In conclusion, the present study has characterised the effects of GH treatment on serum leptin concentrations, BMR and thyroid hormones over a 9-month period. Short-term GH treatment decreased serum leptin concentrations and increased BMR and thyroid hormone deiodination. In spite of a clear long-term decrease in BF, serum leptin concentrations, EE and thyroid hormones returned to baseline values after 9 months of GH treatment. These long-term effects of $\mathrm{GH}$ on serum leptin, EE and thyroid hormones could be of importance for the maintenance of a lower BF mass.

\section{Acknowledgements}

The staff at the Clinical Metabolic Laboratory and the Research Centre for Endocrinology and Metabolism are gratefully acknowledged for their technical support. We also acknowledge the skilled technical assistance of Malin Ottosson, Ulla Karlsson and the statistical advice of Anders Odén. The study was supported by grants from the Swedish Medical Society, the Göteborg Medical Society, Sahlgrenska University Hospital and the Swedish Medical Research Council (grants 05239, 1162101A, 11285, 11331, 11502, 11576).

C Karlsson and K Stenlöf contributed equally to this work and should both be regarded as first authors.

\section{References}

1 Zhang Y, Proenca R, Maffei M, Barone M, Leopold L \& Friedman JM. Positional cloning of the mouse obese gene and its human homologue. Nature 1994372 425-432.

2 Maffei M, Halaas J, Ravussin E, Prately RE, Lee G-H, Shang Yet al. Leptin levels in human and rodent: measurement of plasma leptin and ob RNA in obese and weight-reduced subjects. Nature Medicine 19951 1155-1161.

3 Considine RV, Sinha MK, Heiman ML, Kriauciunas A, Stephens TW, Nyce MR et al. Serum immunoreactive-leptin concentrations in normal-weight and obese humans. New England Journal of Medicine $1996334292-295$.

4 Campfield LA, Smith FJ, Guisez Y, Devos R \& Burn P. Recombinant mouse OB protein: evidence for a peripheral signal linking adiposity and central neural networks. Science $1995269546-$ 549.

5 Lee G-H, Proenca R, Montez JM, Carroll KM, Darvishzadeh JG, Lee JI et al. Abnormal splicing of the leptin receptor in diabetic mice. Nature $1996379632-635$.

6 Havel PJ, Kasim-Karakas S, Mueller W, Johnson PR, Gingerich RL \& Stern JS. Relationship of plasma leptin to plasma insulin and adiposity in normal weight and overweight women: effects of dietary fat content and sustained weight loss. Journal of Clinical Endocrinology and Metabolism 199681 4406-4413.

7 Geldszus R, Mayr B, Horn R, Geisthövel F, von zur Mühlen A \& Brabant G. Serum leptin and weight reduction in female obesity. European Journal of Endocrinology 1996135 659-662. 
8 Veldhuis JD, Iranmanesh A, Ho KKY, Waters MJ, Johnson ML \& Lizarralde G. Dual defects in pulsatile growth hormone secretion and clearance subserve the hyposomatotropism of obesity in man. Journal of Clinical Endocrinology and Metabolism 199172 51-59.

9 Stenlöf K, Sjöström L, Lönn L, Bosaeus I, Kvist H, Tölli J et al. Effects of recombinant human growth hormone on basal metabolic rate in adults with pituitary deficiency. Metabolism $19954467-74$.

10 Stenlöf K, Johansson J-O, Lönn L, Sjöström L \& Bengtsson B- $\AA$. Diurnal variations in twenty-four-hour energy expenditure during growth hormone treatment of adults with pituitary deficiency. Journal of Clinical Endocrinology and Metabolism 1997 82 1255-1260.

11 Johannsson G, Mårin P, Lönn L, Ottosson M, Stenlöf K, Björntorp $\mathrm{P}$ et al. Growth hormone treatment of abdominally obese men reduces abdominal fat mass, improves glucose and lipoprotein metabolism, and reduces diastolic blood pressure. Journal of Clinical Endocrinology and Metabolism 199782 727-734.

12 Clark RG, Mortensen DL, Carlsson LMS, Carlsson B, Carmignac D \& Robinson ICAF. The obese growth hormone $(\mathrm{GH})$-deficient dwarf rat: body fat responses to patterned delivery of $\mathrm{GH}$ and insulin-like growth factor-I. Endocrinology 1996137 1904-1912.

13 Florkowski CM, Collier GR, Zimmet PZ, Livesey JH, Espiner EA \& Donald RA. Low-dose growth hormone replacement lowers plasma leptin and fat stores without affecting body mass index in adults with growth hormone deficiency. Clinical Endocrinology $199645769-773$.

14 Berneis K, Vosmeer S \& Keller U. Effects of glucocorticoids and of growth hormone on serum leptin concentrations in man. European Journal of Endocrinology 1996135 663-665.

15 Carro E, Señaris R, Considine RV, Casanueva FF \& Dieguez C. Regulation of in vivo growth hormone secretion by leptin. Endocrinology 1997138 2203-2206.

16 Ferrannini E. The theoretical bases of indirect calorimetry: a review. Metabolism 198837 287-301.

17 Schofield WN. Predicting basal metabolic rate, new standards and review of previous work. Human Nutrition: Clinical Nutrition 1985 39C (Suppl 1) 5-41.

18 Lindroos A-K, Lissner L \& Sjöström L. Validity and reproducibility of a self-administered dietary questionnaire in obese and nonobese subjects. European Journal of Clinical Nutrition 199347 $461-481$.

19 Kvist H, Chowdhury B, Sjöström L, Tylén U \& Cederblad A. Adipose tissue volume determination in males by computed tomography and ${ }^{40} \mathrm{~K}$. International Journal of Obesity 198812 249-266.

20 Chomczynski P \& Sacchi N. Single-step method of RNA isolation by acid guanidinium thiocyanate-phenol-chloroform extraction. Analytical Biochemistry 1987162 156-159.

21 Carlsson B, Lindell K, Gabrielsson B, Karlsson C, Bjarnason R, Westphal $\mathrm{O}$ et al. Obese (ob) gene defects are rare in human obesity. Obesity Research 19975 30-35.

22 Pelleymounter MA, Cullen MJ, Baker MB, Hecht RH, Winters D, Boone $\mathrm{T}$ et al. Effects of the obese gene product on body weight regulation in ob/ob mice. Science 1995269 540-543.

23 Haalas JL, Gajiwala KS, Maffei M, Cohen SL, Chait BT, Robonowitz $\mathrm{D}$ et al. Weight-reducing effects of the plasma protein encoded by the obese gene. Science 1995269 543-546.

24 Hartman ML, Veldhuis JD, Johnson ML, Lee MM, Alberti KG, Samojlik E et al. Augmented growth hormone (GH) secretory burst frequency and amplitude mediate enhanced $\mathrm{GH}$ secretion during a two-day fast in normal men. Journal of Clinical Endocrinology and Metabolism 1992 74 757-765.

25 Flier JS. Leptin expression and action: new experimental paradigms. Proceedings of the National Academy of Sciences of the USA 199794 4242-4245.

26 Lönnqvist F, Arner P, Nordfors L \& Schalling M. Overexpression of the obese (ob) gene in adipose tissue of human obese subjects. Nature Medicine 19951 950-953.

27 Hamilton BS, Paglia D, Kwan AYM \& Deitel M. Increased obese mRNA expression in omental fat cells from massively obese humans. Nature Medicine $19951953-955$.

28 Zheng D, Jones JP, Usala SJ \& Dohm GL. Differential expression of ob mRNA in rat adipose tissues in response to insulin. Biochemical and Biophysical Research Communications $1996218434-437$.

29 Cumin F, Baum H-P \& Levens N. Leptin is cleared from the circulation primarily by the kidney. International Journal of Obesity $1996201120-1126$.

30 Sinha MK, Opentanova I, Ohannesian JP, Kolaczynski JW, Heiman $\mathrm{ML}$, Hale $\mathrm{J}$ et al. Evidence of free and bound leptin in human circulation: studies in lean and obese subjects and during short term fasting. Journal of Clinical Investigation 199698 1277-1282.

31 Glass AR \& Kushner J. Obesity, nutrition, and the thyroid. The Endocrinologist $19966392-403$.

Received 9 October 1997

Accepted 19 January 1998 